\title{
Book Review Essay: Pimp State: Sex, Money, and Equality by Kat Banyard
}

Christopher Adam Bagley

Public Health Institute, Liverpool John Moores University, chrisbagley2@gmail.com

Follow this and additional works at: https://digitalcommons.uri.edu/dignity

Part of the Education Commons, Life Sciences Commons, Medicine and Health Sciences Commons, Social Work Commons, and the Sociology Commons

\section{Recommended Citation}

Bagley, Christopher Adam (2017) "Book Review Essay: Pimp State: Sex, Money, and Equality by Kat Banyard," Dignity: A Journal of Analysis of Exploitation and Violence: Vol. 2: Iss. 2, Article 6. https://doi.org/10.23860/dignity.2017.02.02.06

This Book Review Essay is brought to you for free and open access by DigitalCommons@URI. It has been accepted for inclusion in Dignity: A Journal of Analysis of Exploitation and Violence by an authorized editor of DigitalCommons@URI. For more information, please contact digitalcommons-group@uri.edu. 


\title{
Book Review Essay: Pimp State: Sex, Money, and Equality by Kat Banyard
}

\begin{abstract}
In this strongly recommended book, Banyard effectively demolishes six myths which defenders of unregulated commercial sexual exploitation of girls and women offer: 1) "Demand for sex work is inevitable; 2) Being paid for sex is regular service work; 3) Porn is fantasy; 4) Objecting to the sex trade makes you a pearl-clutching, sexually conservative prude; 5) Decriminalizing the entire prostitution trade makes women safe; and 6) Resistance is futile." I add to Banyard's analysis my views on the following topics: 1) the sexual exploitation of minors as an essential part of the commercial sex industry; 2) recent Canadian experience in adopting the 'Swedish model' of criminalizing male clients, but not the women they seek to purchase; and 3) a perspective on the sexual exploitation of children and adolescents from recent work in Bangladesh.
\end{abstract}

\section{Keywords}

Prostitution, pornography, Commercialized sexual exploitation, law, public policy, adolescent sexual exploitation

\section{Creative Commons License}

\section{(c) (i) $\Theta$}

This work is licensed under a Creative Commons Attribution-Noncommercial-No Derivative Works 4.0 License. 


\section{DIGNITY}

Volume 2, Issue 2, Article 6, 2017
A JOURNAL ON

SEXUAL EXPLOITATION

AND VIOLENCE

\title{
BOOK REVIEW ESSAY: PIMP STATE: SEX, MONEY, AND EQUALITY BY KAT BANYARD, FABER AND FABER, LONDON, 2016, 262 PAGES Christopher Adam Bagley \\ Public Health Institute, Liverpool John Moores University, UK
}

\begin{abstract}
In this strongly recommended book, Banyard effectively demolishes six myths which defenders of unregulated commercial sexual exploitation of girls and women offer: 1) "Demand for sex work is inevitable; 2) Being paid for sex is regular service work; 3) Porn is fantasy; 4) Objecting to the sex trade makes you a pearl-clutching, sexually conservative prude; 5) Decriminalizing the entire prostitution trade makes women safe; and 6) Resistance is futile." I add to Banyard's analysis my views on the following topics: 1) the sexual exploitation of minors as an essential part of the commercial sex industry; 2) recent Canadian experience in adopting the 'Swedish model' of criminalizing male clients, but not the women they seek to purchase; and 3) a perspective on the sexual exploitation of children and adolescents from recent work in Bangladesh.
\end{abstract}

\section{KEYWORDS}

Prostitution, pornography, commercialized sexual exploitation, law, public policy, adolescent sexual exploitation

$\mathrm{F}$ OR THIS REVIEWER, Kat Banyard's (2016) Pimp State is the best book on the ethical issues and policy options surrounding the commercialized sexual exploitation of women to have been published in the past 20 years. ${ }^{1}$ In writing this review, I make frequent quotations from Kat Banyard's work, since this seems to me to be the best way of illustrating her clear, meticulously researched and convincing arguments, which lead to her conclusions: "Paying a person for sex acts, and third-party profiteering from it, is commercial sexual exploitation. And, it's high time it took its rightful place on this list of things labeled not for sale" (p. 224). I hope the reader of this review will not treat these quotations as simply a precis of

\footnotetext{
${ }^{1}$ This book, published in England, deserves to be widely read in North America. A call to the publisher in London established that Faber \& Faber have no American office, nor any established US retail outlook. The publisher hoped that potential readers would order the book through Amazon. Janice Raymond's book (2013) covers much the same ground as Banyard, with analysis and proposals which are often similar. But Raymond's scholarly volume is a more challenging read, and because of its reasoned rhetoric, and its didactic impact I prefer Banyard's book. Note too Tyler's (2016) cogent refutation of "myths" offered by those who criticize the Nordic model, using a style of "myth busting" similar to Banyard's.
} 
her book. It deserves to be read in full by all of those seeking to end the commercial sexual exploitation of girls and women.

Writing about policies concerning "sex work" (sic), feminists and pseudofeminists (including some male writers) fall into three groups in the face of what is clearly an area of growing concern in all world countries: the commercial sex industry (including the filming of paid-for or coerced sexual acts, i.e. pornography), and the supply of abused and impoverished girls and women who are required to participate, "willingly," or not.

Policy makers, politicians, and scholars take three main approaches to this growth. The first is to accept the growth of this industry, not only decriminalizing sexual exploitation, but aiding its growth by allowing managers (pimps and politicians) to organise and profit from the organisation of sex work into organised brothels of various kinds, as well as producing filmed prostitution which may induce its consumers either to go on to use human beings, or to provide value support for this sexual exploitation.

The state's involvement leads Banyard to coin the term "Pimp State," epitomized by Germany which has decriminalized many areas of commercialized sexual assault, allowing the importation of impoverished women from poorer parts of Europe. Germany now has more than 400,000 women working in industrialized sexual exploitation, leading some to dub Germany as "Europe's brothel" (Smith, 2016). Rather than recognizing the reality of this exploitation, groups such as Amnesty International have claimed that freeing prostituted women from formal, legal protection promotes their rights. Banyard shows very clearly that the opposite is true: setting free legal constraints increases the flow of poor, ethnically stigmatized and previously abused girls and women into sexual exploitation, enriching pimps and their financial backers, but enriching the women involved not at all. Rather they pay a heavy price regarding their mental and physical health.

The second approach, in the face of what seems to be an overwhelming growth in the power of the pimp state, is that of "realism," in which researchers describe the "real world" of commercialized sexuality, in terms of brutal exploitation and oppression of women, but yet are overwhelmed by the 'pimp state' lobbyists, proposing intermediate rather than radical solutions for the protection of women (e.g. Outshoorn, 2004; Matthews, 2008). Matthews (2015) in a further incisive review of the gross harms which being a commercially sexually exploited person can bring, reaches the surprising conclusion that "... the concept of consent remains problematic because it is often assumed that women involved in prostitution give their consent freely." Given the evidence that Matthews reviews, this is a mild conclusion indeed.

The third approach that Banyard offers is a different kind of feminist scholarship, one that takes no prisoners in seeking to dispel the many "myths" surrounding commercial sexual exploitation. She addresses with a scathing logic those who advocate on behalf of the group of pimps and their supporters (including some women) who seek total freedom (and decriminalization) in putting women to work for the benefit of brothel owners and their customers.

Banyard offers, and then efficiently demolishes "Six Myths" surrounding socalled sex work (the idea of sex as legitimate female work, which women freely choose and profit from). I can best illustrate her thesis through a series of quotations, since merely summarizing her eloquent prose will not serve her thesis fully: 
"The claim that building a feminist future does not necessitate the abolition of the sex trade is not some esoteric, ivory tower hypothesis. It's a contention that today underpins a global bid for governments to accept, regulate and accommodate the trade. This book is a challenge to that bid" (p. 5). Banyard outlines "five myths" manufactured by advocates of freedom for pimps and the women they control.

\section{Myth 1: Demand for the sex trade is inevitable}

In addressing this idea, Banyard draws on the qualitative and quantitative research by herself and others to show that "Dehumanisation and misogyny enable the transaction. Without it, the sex trade could not survive" (p. 51). Numerous examples show that "ordinary," loving, family men are capable of atavistic acts of cruelty and callousness. Its origin lies in what Freud called the Id, the dark lusts that lurk in the phylogenetically old brain. Users of paid-for sex frequently resort to the debasement of the woman, inflicting vicarious cruelties, physical and verbal. It's as if they have to maintain a sub-ego state to perpetuate the sexual transaction. But an appeal to the ego, the "better nature" of these men may also be highly effective, as Banyard's interviews show: realizing that the woman is human, and hates servicing customer after customer is often detumescent. Coming to sympathize with the bought-for women, this slave to a man's sexual desire, creates discomfort in both customers and in society at large. Appealing to the better side of human nature could be an important way forward for those seeking to end the sexual exploitation of women.

\section{Myth 2: Being paid for sex is regular service work}

Even the World Health Organisation, wrestling with the dilemma of an everincreasing demand for the sexual use of impoverished, previously abused and trafficked women, retreats into the myth of "the free market" in which women willingly sell themselves into roles which involve painful and degrading sexual abuse, Nevertheless, "The whole point of the sex industry is that it offers men the chance to buy sexual access to women who do not want to have sex with them. This is the whole point. Otherwise, they wouldn't have to pay" (p, 66) (Italics in original). "The very act of paying someone to participate in sex acts is abusive" (p. 67). For many women, being sexually abused in adult prostitution is simply a continuation of the sexual assaults they experienced as children and adolescents. As one of her adult interviewees told Banyard: "... I was used to getting my boundaries violated from my childhood, so I didn't think anything of it ...” (p. 69).

There is abundant evidence that women (and men) who become commercially sexually exploited individuals have, often in more than a half of cases, endured sexual, emotional, and/or physical abuse in childhood and adolescence. Running from home (or being removed into "care") is often a pathway into selling sex for survival, being prey to pimps and trafficking, become substance addicted, suffering PTSD-inducing trauma, devastated self-esteem, and dissociation from the abuse of enforced adult prostitution (Sawyerr \& Bagley, 2017a). The man who pays to sexually abuse adult women is re-enacting and re-imposing this pattern of earlier abuse. Adolescents who are victims of commercial sexual exploitation (not much discussed by Banyard) fetch higher prices, partly because men enjoy "fresh meat"; some have pedophile impulses; or because they know that the younger the victim, the more physical, emotional and sexual pain she will endure. There are elements of both sadism and empowerment for men who purchase children and adolescents for sexual purposes. 
"Regardless of routes in, the fact that the sex trade is founded upon the absence of mutual sexual desire means that the principle predicament becomes how to endure repeated sexual abuse. Not just to endure it, but appear to want it - lest it may be deemed 'bad service' ... Strangely enough, it turns out that legalizing brothels and dubbing what goes on inside as 'sex work' does not magically transform women into insentient sex dolls. They experience it as rape” (p. 76-79). Soon, the only motivation for continuing as a 'perpetual rape victim' is to acquire money to feed a continuing drug habit. Dissociation from rape after rape after rape can be dangerous, leading to women failing to recognize or escape from dangerous men. Dissociation may lead to psychosis. One way of escaping is by drug overdoses, or by suicide as we found in our research in Bangladesh (Bagley at al., 2017).

Other ways of escape are blocked by hopelessness and despair. The prostituted woman becomes a creature, a slave of her owner, of her customers, and of the society which tolerates her abuse. "A society that acts in law and language as if men who pay to sexually access women are simply consumers, legitimately availing workers of their services, is a society deep in denial about sexual abuse - and the sex inequality underpinning it” (p 93).

\section{Myth 3: Porn is fantasy}

Kat Banyard's comprehensive deconstruction of the myths surrounding pornography is the most powerful, and best argued part of her book. She argues that pornography is in fact filmed prostitution (with male actors also prostituting their sexuality), and acts to reinforce myths about prostitution and its seemingly voluntary nature, as evidenced by the increase in the size of the prostitution industry and the spread of legalised brothels - places where men require the women to recreate the sadistic fantasies they have viewed numerous times in pornographic videos. "Pornography isn't fantasy - it's a corporeal trade that extracts profits from sexual abuse, fulfilling a demand that sex inequality created" (p. 106). Not only sexual inequality (woman as sexual object, who enjoys humiliation and pain) but racism as well in popular video series such as "Exploited black teens," "Ghetto gaggers," "Latina abuse" and "Asian street whores."

"Maintaining that the pornography trade is not an industrialised form of sexual abuse relies on the fantastical notion that porn studios have somehow managed to create a kind of economic and sexual nirvana: a place where women's desire to have sex is miraculously in sync with the director's schedule; where she happens to want and like all the sexual acts required by the director and which just happen to be the sexual acts which are the most profitable for the said director ... where there is zero coercion and pressure from agents, directors and production companies ... It's like an absurd parody of the neoclassical economist's wet dream of 'perfect competition, perfect information, and perfect rationality"' (p. 113).

Banyard cites a number of studies, conveniently ignored by advocates of the legalized pimp state, showing that for the large majority of women, being a sexualised object in a pornographic movie or in a legalized brothel - the experience is both dreadful and demeaning. Pornography gives a model to adolescents and older males of how women should be treated with lordly aggression, however much they may privately complain in the mute dissociation of their minds and bodies from the sexual exploitation. "That the filmed prostitution peddled by porn studios inspires misogynistic beliefs and sexist violence isn't a hunch ... It is the clear and

consistent finding from over four decades of academic inquiry. The attitudes that 
pornography inculcates and the accompanying feelings it elicits can foster a predisposition, as well as squash internal and external inhibitions, to perpetuate sexual abuse" (p. 121). Thus, pornography doesn't just stimulate sexual arousal; it creates a cognitive schema, a mental framework for interpreting and acting in realworld situations, serving as a kind of sexual script, guiding expectations in relation to future attempts at a sexual relationship, with an unwilling (paid for) or apparently willing sexual partner.

Pornography, on this evidence, is both a driver of the appetite for paid-for sex, and of the violent and dehumanizing sex that is required of future partners. Thus, filmed prostitution is "politically toxic," and is a useful device for those who argue that all paid-for sex should be legalized, given the (false) premise that women enjoy being sexually abused; and the true premise that legalizing all paid-for sex will be highly lucrative, for some at least.

\section{Myth 4: Objecting to the sex trade makes you a pearl-clutching, sexually conservative prude}

In this section, Banyard effectively demolishes the hostile campaign against feminists who, in defense of sexually exploited women, argue against the growth of brothels which both enrich an exploiting class and impoverish the women who are forced to work in them. It is not enough to produce a few pseudo-feminists who say they enjoy having sexual intercourse 20 times a day and want to extend such benefits to every woman in the land. For every woman pimp and pornographer, Banyard and others who work at the front line can produce a hundred women who hate what they do but are trapped by addictions, hopelessness, or the slavery that follows being trafficked. Women in sex "work" suffer daily hurts, physical and psychological. Most receive only a fraction of what a customer pays, but still, have to endure the excited lust of the man whose ego is enhanced by debasing another human being. The advocates of free-enterprise prostitution try and minimize the harms which sex work brings: yet among the strutting customers there are psychopaths who hurt and kill. The death rate of prostituted women is higher than in any other occupation on earth, including the military. But for the pimping class and those who (in many cultures, the police and government officials they bribe) the stakes are very high, and harassing women and men who object to for-profit brothels is an important activity.

\section{Myth 5: Decriminalise the entire prostitution trade, and you make women safe}

Once again, Banyard introduces a powerful set of arguments which demolish this myth. She examines in detail those countries which have removed most laws surrounding sex work, such as Germany, The Netherlands and New Zealand. Such approaches both ignore the abuses which are antecedent to, and which endure in commercialized sexual exploitation. Governments have been overwhelmed by the magnitude of the problems of sex work which face legislators, and some have chosen therefore to allow sexual exploitation of girls and women its full, unbridled force. "As I will show, on multiple counts, full legislation or so-called decriminalization simply magnifies these harms. The contradictions and casualties wrought by these testing grounds reveal the mythical nature of claims that the sex trade can be treated as a form of work, which decriminalization will make "safe" (p. 164). 
One of the consequences of the "hands off," decriminalization policy is that the exploited women are now largely unprotected by any legal authority. The net result seems to be an increase in unreported violence, in some cases an unrestricted recruitment and sale of juveniles, and the trafficking of women from Africa and poorer regions of Europe, into slavery-like conditions. Conditions of licensing are liberal: most anyone can start a brothel, and the regulating authorities, such as they are, include people who have a commercial interest in brothels, strip clubs, and massage parlors. "What makes pimping impervious to government decrees that prostitution is merely 'work' is that the apt comparison for the relationship concerned is not that of agent and client, but domestic violence ... Pimping is a commercial sexual exploitation. Making it legal does not miraculously deter would-be exploiters, nor support those they subject to coercive control to get away from prostitution" (pp. 166 \& 168).

Dutch research shows that complete freedom for those who prostitute women has led to an increase in trafficking across national boundaries (and all of the force, violence, and coercion that this involves), and an increase in the number of prostitutes, and in the number of men who use them. Legalization has been a boon to those men who seek to profit commercially from this industry. New Zealand research shows that legalization has led to increased acts of violence against women, who now have fewer people from whom they can seek help. "Legalised prostitution regimes embody the fundamentally abhorrent notion of attempting to create a 'clean, safe place' for paying punters to commit sexual abuse in" (Banyard, p. 175).

Prostitution in some countries may be an accepted "industry," but the control of the conditions of work fall far below those ensured for other commercial sectors. Women do not have contracts of employment, sick pay, or vacation leave rights. What is the point of giving a drug-addicted, illegal immigrant vacation rights? The standard position (e.g. in New Zealand) seems to be that the women sex laborers are "self-employed," and must arrange their own social security benefits, etc. If clients infect women with STIs, there is only atypically any "health care package" which they can access. Police or social agencies can be legally denied entry to the enclosed sexual work places, making it much easier to abuse and maltreat women, and to employ juveniles (Banyard, p. 178).

Particularly in Germany, prostitution is a growth industry, with many thousands of migrants shipped in to do sex work. Physical coercion and enforced drug addiction are useful ways of ensuring high productivity by the units of sex for sale. "Legality contributes to normalization, which in turn increases the likelihood of paying for sex" (p. 181). Governments of these pimp states (who may collect some tax revenue from the 'owners' of the women) are very reluctant to fund social programs which would enable women to leave prostitution. After all, if the sex trade is a normal, free choice, why don't women simply walk away? To admit that women might need help in leaving would undermine the self-deluding ideology of governments and municipalities who permit the trade (Banyard, p. 185).

The ultimate, self-deluding insult is Amnesty International endorsing full decriminalization of the sex-trade - brothel-keeping and pimping included - 'to protect the human rights of sex workers.' Even the World Health Organization (WHO) and UNAIDS has endorsed this policy, under the false premise that "free" sex workers will be better able to persuade customers to use condoms and to seek medical help when infection occurs. This, Banyard suggests, is a counsel of despair, 
a giving up in the face of what seems to be an overwhelming tide of the demands of male sexuality for indulgence and fulfillment.

But there is an alternative: 'the sex-buyer law,' which Banyard reviews in some detail. This approach, which has been the basis of law in Sweden since 1999, criminalizes the buying of sex from an individual but absolves those who are offered money or goods (e.g. drugs) of any crime, even if they accept the buyer's proposition. This law has been extended to various other Nordic countries, to Northern Ireland, and most recently to France and Ireland, and Canada in 2014. Banyard's research with her Swedish sources suggests that in its early years this law was inefficiently administered, and few men were charged. More recently, however, police have been more proactive, and the public norm that it is illegal and therefore "wrong" to sexually exploit women through payment for sex, has become much more widely accepted. The sequel is that there is evidence that the practice of prostitution in any form is also declining. "What is inconvenient for groups wanting governments to enshrine brothel-keeping and pimping as legitimate jobs is that the effects of the Sex Buyer Law have so clearly exposed the fatalism of some authorities surrounding prostitution. Street prostitution in Sweden halved between 1999 and 2008" (p. 193).

Surveys of male respondents suggested too that the number using commercial sex halved over the same period, compared with Denmark where buying sex remained legal. Another benefit was that the cash flow to organized crime (the usual beneficiaries of sexual exploitation) greatly diminished, and these men looked elsewhere in Europe for profit-taking. Trafficking of young women for sexual purposes seems to have ended too. The commercial sex industry was not driven underground. Moreover, murders of commercial sex workers in Sweden have greatly diminished (involving one woman, killed by her ex-marital partner). Comparing Sweden and The Netherlands and adjusting for population size, the murder rate of commercially sexually exploited women in The Netherlands (where there is a freefor-all, the absence of law) was 70 times greater than in Sweden (Banyard, p. 202). Police informants in Sweden made it clear how easy it was to apprehend men trying to buy sex: commercialized sex must have modes of contact, and intermediaries to link buyer and the woman, adolescent or child who will be used sexually. Police can, with ease, infiltrate those networks.

The Canadian law was introduced late in 2014, and no evaluative studies were available for Banyard to access. My contacts in Alberta, Canada ${ }^{2}$ indicate that in its first two years of operation, very few men arrested for attempting the commercial procurement of sex. And not a single man had been required to pay the $\$ 2,000$ fine for having sex with a commercially exploited individual aged less than 18 , despite the fact that in Alberta and British Columbia, prior to 2014 at least ten percent of "street girls" were under 18, with a probably greater number of younger girls working "inside," usually in rooming houses close to bars known to potential customers (Hay, 2004). In Vancouver, in June 2015 no men had been prosecuted, and pimps continued to work unhindered (Lye, 2016).

Working in Calgary in the 1990s we were astonished at how easy it was to be directed to the "sexual services" of a very young teenager (Bagley \& King, 2003). Police were clearly aware of this traffic but rarely intervened. Many of these young

${ }^{2}$ King (2016); and Kathleen King, personal communications. 
girls had been trafficked from other Canadian cities, ostensibly to break their friendship and kinship ties which might have given opportunities for exit, enabling the pimp/boyfriend to increase his emotional (and violent) hold on the victim. I must pose, once again the question (as does Banyard): if the average "john" can find an adolescent to purchase for sex by visiting a few bars in seedier parts of a city, how come the police do not access these networks of information, and end the commercialized sexual abuse of adolescents?

A weakness in the Canadian law is that it allows Provincial jurisdictions (e.g. Alberta) to licence massage (sic) parlours, with rooms which girls are allowed (or forced) to rent, in which customers are then legally allowed to be massaged, and for an extra fee can have the woman perform oral sex, if they wear a condom. (The high rents charged mean that a woman will have to service at least 20 customers a day in this manner). Police do not see this as "actual" intercourse, which would incur a legal penalty. Verbal and physical violence takes place in these parlors, and occasionally, rape which is never, in the Canadian situation, prosecuted. The Canadian government in 2016 allocated $\$ 20$ million for programs for enabling victims of commercial sexual exploitation to exist this demeaning trade. Parceled out amongst Canadian cities, this amounted to a little over $\$ 100 \mathrm{~K}$ a year. This amount will employ one worker, and offer limited help for exit support programs. It is not enough. The Canadian model is in its infancy, and we can hope for better funding and more imaginative programs in future years.

In comparing societies, this reviewer offers the opinion that the policies for young women to avoid or exit commercial sexual exploitation do not work in isolation from the values of social structure, at local and national levels. That is why, in our opinion, the Swedish model works, because an enlightened set of values embedded in many social institutions, allows for the legal protection of women from commercial sexual exploitation, and educates and informs men in non-sexist modes of relationship.

Of course, an adequate legal framework is needed, but society's values need to change at a fundamental level for the law to be properly administered. That is why programs in the United Kingdom and Canada are failing: civility, care, tenderness, respect, dignity, equality between sexes are values which must be developed at a culture's most basic levels, at the family, community and school levels (Sawyerr \& Bagley, 2017b). Thus, despite its policy of total liberation of the commercial sex exploitation industry, New Zealand may be moving towards a Swedish model, of police acting to protect commercially exploited sex workers (Armstrong, 2016), reflecting broader value changes.

\section{Myth 6: Resistance is futile}

No, resistance is powerful and growing. Imagine there's no sex trade, that children are protected from sexual abusers, that they do not have to escape to the streets, sell sex for survival, and are often dragged into commercial sexual exploitation; where men and women treat one another with affection and respect, where sexual relations are part of a voluntary contract, without financial inducements; where women are not captured and shipped across national and state lines, in conditions of sexual servitude: imagine: it's not hard to do.

One policy development not addressed by Banyard is that of apparently progressive interventions to help prostituted women and adolescents in some American cities, in which both men, and the women they exploit, are criminalised: 
but women are diverted into effective counselling programmes, rather than punished (e.g.Clayton, Krugman \& Simons, 2013; Barnert et al., 2016). This work also highlights the need for early intervention programs at family, school, and street level aimed at protecting 'at-risk' youth being pulled into 'survival-sex' and drug-using subcultures, major routes into adult sexual exploitation.

The "filmed prostitution" of pornography could be treated in a similar legal way as criminalization of profit-takers from sexual exploitation, given the evidence that Banyard produces on the gross abuses of power and sexual assaults involved in this pornography industry. This would be an interesting case for the US Supreme Court to decide on: that filmed reproductions of prostitution are not ipso facto, different from the practice of prostitution itself, with pornographers being involved in the (punishable) commission of an illegal, public display of sexual assault.

In demolishing the myth that "resistance is futile," Banyard is both angry and cheerful. "Cut through the myths, and it's clear the sex trade is a phenomenon entirely of our creation: industrial-scale sexual exploitation, born of sexual inequality, and midwived by third-party profiteers - profiteers whose exploits get a helping hand from factors like abuse, neglect, racism and poverty. We made this. We can unmake it" (p. 211). The first weakness she identifies is that "The sex trade is reliant on mainstream institutions, but they [the institutions of society] are not reliant on it" (p. 215). If the appetite for degraded sexuality is reduced, sex profiteers suffer; society doesn't. Thus evidence-based lobbying by people of goodwill the alliance of academics, feminists opposed to female degradation, and community leaders - is a worthwhile alliance.

The second weakness in sex trade profiteering is the fact that the sex trade needs men to regurgitate its myths, and people of goodwill to keep quiet (p. 219). But men and women of goodwill are not keeping quiet, as Banyard shows with several examples. Thirdly, "Setting limits to the market is hardly revolutionary. The effect will be" (p. 222). The selling of sexual exploitation and degradation of human beings is not acceptable, just as the selling of degraded humans through the sale of their enforced manual labor (the slavery of previous centuries) was only acceptable to those who profited from slavery. That is where we are now, campaigning against the slavery inherent in commercialized sexual oppression. Kat Banyard stands in the tradition of William Wilberforce, Harriet Beecher Stowe, and those who pioneered universal suffrage. This march of progress must have an eventual victory, when human society regards as outrageous the enslavement inherent in requiring another human being to debase themselves sexually, in a commercial transaction.

Excellent though this book is in reviewing the current sociology of pornography and prostitution, and evidence concerning various commercial and legal settings, there are some missing pieces. These omissions do not weaken Banyard's thesis, but their addition can strengthen her arguments if they are applied to other aspects of commercialized sexual exploitation. First of all, some of her female informants mention prior histories of childhood abuse, as a factor leading them into CSE, and some studies are cited (e.g. 50\% of adult sexually exploited women endured child sexual abuse). This and other literature (e.g. Mitchell, Finkelhor \& Simmons, 2013; Kaetle, 2012; Sawyerr \& Bagley, 2017a) leads to the powerful conclusion that: the commercialized sexual exploitation (CSE) of adult women cannot conceptually be distinguished from the abuse, neglect, and exploitation experienced by a child or adolescent (sexual, emotional and physical abuse, family disruptions and adverse childhood events, and impacts of poverty and racism). 
According to this thesis, the sexual abuse of adult women will end only when the physical, emotional and sexual subjugation of female children and adolescents (through various forms of abuse) is ended. We have argued (Bagley \& King, 2003) that the sexual and physical abuse of children is often a form of socialization through which female children are, through their depressed self-concept (Sawyerr \& Bagley, 2017b), prepared for adult roles such as being subordinated and exploited sexuality in both general and specific ways.

Working in the field of child sexual abuse (and of child and adult prostitution) I can appreciate why Banyard does not ask about use of underage girls by her male informants: no man is likely to admit overtly to child sexual abuse. And when one works with underage sexually-exploited individuals, ethical research procedures require both that one has a viable "rescue plan" for the individual to exit sex work; and also, those with knowledge of male exploitation of minors must report this to a law enforcement agency. Thus, Banyard tends in her research to skirt round "the elephant in the room" (King, 2016), the sexual exploitation of children and adolescents which is the essential underpinning of a successful sex industry. She acknowledges this fact but does not emphasize it strongly enough.

Another facet of commercial sexual exploitation which Banyard does not address is the movement of adults leaving CSE roles, who campaign for the amelioration of the conditions of sexual labour, as a prelude to ending coerced conditions, and who also campaign for stopping the introduction of minors (without which the sex exploitation industry cannot flourish). Our research in Bangladesh (Bagley et al., 2017) suggests that these resilient women when they grow in numbers and confidence, not only seek to end CSE of minors: they seek to end CSE altogether through meaningful forms of alternative income support.

Another issue (not touched on by Banyard) in confronting police and government systems, is their corruption in taking a cut from CSE earnings, and actively promoting the sexual exploitation of minors, whose work yields larger bribes from pimps. Banyard does not focus on police corruption, presumably because it is rare in Europe and North America. But this is a profound problem for the millions trapped in the sex industries of Asia (Bagley at al., 2017), and does still pertain in some European countries (e.g. Ordinokova et al., 2014).

Another aspect of commercialised sexual exploitation only briefly touched on by Banyard, is the imposition of STIs (sexually transmitted infections) and HIV on girls and women - especially likely when powerless adolescents and women are forced to avoid condoms in sexual transactions (Clarke et al., 2012; Goldenberg et al., 2014; McLure \& Chandler, 2015).

I end this review with a brief vignette of "Ami," who was nine when we met her on the streets of Dhaka, Bangladesh. She had been forced to perform sexual acts since the age of five. Condoms were never used, and she received about US 25 cents per transaction. Our team found that Ami was HIV-infected. We paid for her hospital treatment and medication, but she died earlier this year of drug-resistant tuberculosis (TB). We failed to save her life. The prophets of the great world religions have said, "If you save one life, you save the whole world." We are trying to save the world, one child at a time. 


\section{AUTHOR BIOGRAPHY}

Christopher Adam Bagley is a Muslim-Quaker. He has held chairs of child welfare, applied social studies, and social work at universities in Canada, Hong Kong, and Britain. He is currently Professor of Social Science at the Public Health Institute, Liverpool John Moores University, UK. Among his current projects is one supporting positive identity development in gay Muslim men.

\section{RECOMMENDED CITATION}

Bagley, Christopher Adam. (2017) Book Review Essay: Pimp state: Sex, money, and equality. Dignity: A Journal of Sexual Exploitation and Violence. Vol. 2, Issue 2, Article 6. doi:10.23860/dignity.2017.02.02.06. Available at http://digitalcommons.uri.edu/dignity/vol2/iss2/6.

\section{REFERENCES}

Armstrong, L. (2016). From law enforcement to protection? Interaction between sex workers and police in a decriminalized street-based sex industry. British Journal of Criminology, February 18, Online.

Bagley, C., Khadri, S., Shanaz, A., Simkhada, P. \& King, K. (2017). Commercialized sexual exploitation of children, adolescents and women: health and social structure in Bangladesh. Advances in Applied Sociology, 7, 137-150.

Bagley, C. \& King, K. (2003). Child Sexual Abuse: The Search for Healing. London and New York: Routledge.

Barnert E, Abrams S, Azzi V \& Three Others (2016). Identifying best practices for "Safe Harbor" legislation to protect child sex trafficking victims: Decriminalization alone is not sufficient. Child Abuse and Neglect, 51:249-62.

Clarke, J., Clarke, E., Roe-Sepowitz, R. \& Fey, R. (2012). Age at entry into prostitution: relationship to drug use, race, suicide, educational level, childhood abuse, and family experiences. Journal of Human Behavior in the Social Environment, 22, 270-289.

Clayton E., Krugman R. \& Simon P. (Eds.). (2013). Confronting Commercial Sexual Exploitation and Sex Trafficking of Minors in the United States. Institute of Medicine and National Research Council. Washington, DC: National Academies Press.

Goldenberg, S., Chettiar, J., Simo, A. \& Five Others (2014). Early sex work initiation independently elevates odds of HIV infection. Journal of Acquired Immune Deficiency Syndrome 65, 122-128.

Hay, M. (2004). Commercial sexual exploitation of children and youth. BC Medical Journal, 46, 119-122.

Kaetle, C. (2012). Selling and buying sex: a longitudinal study of risk and protective factors in adolescence. Prevention Science, 13, 314-322.

King, K. (2016). Elephants in the room. The Advocate: Alberta College of Social Work Journal, 41, 26-28.

Matthews, R. (2008). Prostitution, Politics and Policy. London: Routledge.

Matthews, R. (2015). Female prostitution and victimization: a realist analysis. International Review of Victimology, 21, 85-100.

McClure, C. \& Chandler, S. (2015). Responses to HIV in sexually exploited children or adolescents who sell sex. The Lancet, 385, 97-99. 
Mitchell, K., Finkelhor, D. \& Wolak, J. (2009). Conceptualizing juvenile prostitution as child maltreatment: findings from the national juvenile prostitution study. Child Maltreatment, 15, 18-36.

Odinokova, V., Rusakova, Vrada, L., Silverman, J. \& Raj, A. (2014). Police sexual coercion and its association with risky sex work and substance use behaviors among female sex workers in St. Petersburg and Drenburg, Russia. International Journal of Drug Policy, 25, 96-104.

Outshoorn, J. (2004). Voluntary and forced prostitution: the realistic approach. In J. Outshoorn (Ed.) The Politics of Prostitution: Women's Movements, Democratic States and the Globalisation of Sex Commerce (pp185-206). Cambridge, UK: Cambridge University Press.

Raymond, J. (2013). Not a Choice, Not a Job: Exploring the Myths about Prostitution and the Global Sex Trade. Washington, DC: Potomac Books.

Saewyc, E. \& Edinburgh, L. (2010). Restoring healthy developmental trajectories for sexually-exploited young runaway girls: fostering protective factors and reducing risk behaviour. Journal of Adolescence Health, 46, 180-188.

Sawyerr, A. \& Bagley, C. (2017a) Child sexual abuse and adolescent and adult adjustment: A review of British and world evidence, with implications for social work, mental health and school counselling. Advances in Applied Sociology, 7, 1-15.

Sawyerr, A. \& Bagley, C. (2017b). Equality and Ethnic Identities: Studies of Self-Concept, Child Abuse and Education in a Changing English Culture. Leiden: Brill-Sense Education Series.

Shields, R \& Letourneauu, E. (2015). Commercial sexual exploitation of children and the emergence of safe harbor legislation: implications for policy and practice. Current Psychiatry Reports, 17, 553-555.

Smith, J. (2016). Pimp State: Sex Money and the Future of Equality by Kat Banyard review. The Guardian Online, June 20.

Tyler, M. (2016). Ten myths about prostitution, trafficking and the Nordic model. In C. Norma \& M.T. Reist (Eds.) Prostitution Narratives: Stories of Survival in the Sex Trade (pp. 213-225). Melbourne: Spinifex. 